\title{
Comparative Study on Analysis and Design of Reinforced Concrete Building under Seismic Forces for Different Codal Guidelines
}

\author{
Tabish Izhar' ${ }^{1}$, Samreen Bano ${ }^{2 *}$, Neha Mumtaz ${ }^{3}$ \\ ${ }^{1,3}$ Assistant Professor, ${ }^{2}$ M. tech Scholar \\ 1,2,3 Department of Civil Engineering, Integral University, Lucknow, U.P, India
}

\begin{abstract}
How to cite this paper: Tabish Izhar | Samreen Bano | Neha Mumtaz "Comparative Study on Analysis and Design of Reinforced Concrete Building under Seismic Forces for Different Codal Guidelines" Published in International Journal of Trend in Scientific Research and Development (ijtsrd), ISSN: 24566470, Volume-3 | Issue-4, June 2019, pp.536-551, URL: https://www.ijtsrd. com/papers/ijtsrd2 3819.pdf

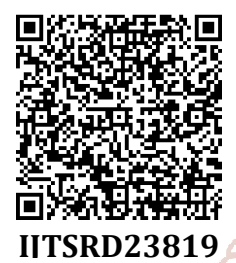

Copyright (C) 2019 by author(s) and International Journal of Trend in Scientific Research and Development Journal. This is an Open Access article distributed under the terms of the Creative Commons

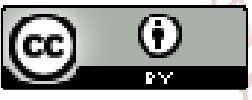
Attribution License (CC BY 4.0) (http://creativecommons.org/licenses/ by $/ 4.0$ )

research on seismology or earthquake engineering began only after the Meiji restoration in 1868.In 1923 Kanto (Tokyo) earthquake caused loss of life more than 14000, heavy damage in building and houses around 250000[1]. In 1908, the Messina earthquake occurred in Sicily, Italy, and Calabria with the magnitude of 7.1. The cities were destroyed and 200,000 lives were lost [4]. In 1989 Loma Prieta and 1994 Northridge earthquake led to a loss of 120 lives. To minimize these losses during earthquake seismic provision have been developed [2].

The Indian seismic code (IS-1893) published in 1962 for the purpose of Recommendation for earthquake resistant design of structures and this revised in 1966 first time. The sectional committee felt to revise these standards including the seismic zones and epicentre in 1970. The third revision in 1984, prepared with a new concept of the performance factor, base shear, and modal analysis was introduced. In 2002, the fifth revision of is 1893 deals with the seismic loads of various structure and earthquake resistant of the building [5].

The building standards law of Japan 1963 revision was removed the height limitation. The law required that the

\section{ABSTRACT}

Construction is a vital part of every developing country in this era. Every country the specific building design codes which provide the standards to engineers for Analysis and design Reinforcement concrete building of every country is based on their geographical location. Seismic forces are one of the major natural forces differe and can appropriate for best guidelines for safety to lives and conomy. In today's world of globalization, an engineer must be efficient enough presented for analysis and design of reinforced concrete building under seismic forces for four codal Guidelines (IS 1893:2002, Euro code 8, Japan-2007 and ASCE: 7-10) using Staad Pro. The comparative study includes the comparison building base shear, bending moment, shear force, percentage of steel, required area, displacement, and story-drift. For seismic Analysis and design, the building elements like beam and column is also compared using these countries RC

Keywords: Seismic analysis, Multi-storeyed RC building, IS, Euro code, ASCE, Japan

\section{INTRODUCTION}

There is major earthquake have been recorded in India, Japan, Europe, and the U.S. The Bhuj earthquake in 2001 in India with the magnitude of 7.7 resulted in 0000 lives and around 339000 severe damage of building [2]. In India, 26 December 2004 Ocean earthquake of a magnitude of 9.1 to 9.3 , resulted in more [1]. Many earthquakes have accrued in Japan, the scientific design and construction of high rise building should be approved by Minister of construction because of the severe damage of high rise building in the 1923 Kanto (Tokyo) earthquake disaster. The urban building law of enforcement order issued in 1920, limited to a building height of 65 feet of residential building and 100 feet of a non-residential building. The method of construction is required in the building of law of enforcement order, revised time to time by the technical development. Various standards and guidelines provided by the Architectural Institute of Japan (AIJ). The building law of Japan (BSLJ) was proclaimed in May 1950 to safeguard the life, health, and property of people. The (BSLJ) order was revised in July 1980 and was adopted from June 1981[6, 7].

The European standards EN 1998-1 Design of structure for earthquake resistance. Euro code consists of 10 sections that were developed by the European Committee for Standardization (CEN). EC-1998-8 concern the design of the structure for earthquake resistant, it is the eight standards of EC-1998 and it is an addition of six parts (EN1998-i: $i=1,2,3$, $4,5,6)$. EC8 was approved and published in 2013, it considers different factor like behavior factor, capacity design method, dissipative zones, importance factor etc $[8,9]$. 
The first modern code containing seismic provision is generally admitted to be the first edition of the uniform building code. National earthquake hazard reduction program recommended provisions developed by building science safety council in the USA (BSSC 1997). In 1937, the zonal map introduced with the concept of the different seismic resistant building. In 1988 UBC revised by structural engineering association of California (SEAOC). The (SEAOC) formed by Applied technology council, consider the introduction of site factor and occupancy importance factor. ASCE-7-10 utilize seismic design category (SDC) concept which differentiates the structure according to the seismic risk level $[10,11]$.

Ahmed M. EI Kholy at al. [3] compare the Egyptian code 2012 with EC 8-2013, IBC 2015 and UBC 1997; consider residential shear wall RC buildings in Egypt. Muhammad Mostafijur at al. [2] present seismic performance of reinforcement concrete buildings designed according to codes in Bangladesh, India, and the USA. The structures were modeled and design software ETABS NL (version 9.6). Masayoshi Nakashima [12] compares EC8 and the Japanese seismic design code (BCJ) for steel moment frames and braced frames. In this paper EC8 is 2.5 times larger force for his limit state. Marjan Faizan and Yuji Ishiyama [13] compare the seismic codes of Japan (BSLJ) 1981; USA (IBC) 2000 \& Iran (ICS) 1999 are used for comparing the similarity and differences. C. Bhatt, R. Bento [14] compares the code of America and European, on the nonlinear static analysis of RC building. In this paper, five stories RC concrete building consider and result compare with nonlinear dynamic analysis. By Weizi Zhang and Bahram m. Shahrooz[15] present the comparison between ACI and AISC for concretefilled tabular columns(CFTs), defined their potential capacity. Angelica Walsh at al. [16] compares three climatic zoning methodologies for structure and find out the difference in results for a small country climatic variation. Sameh A. EI-Betar [17] presents the seismic performance of existing RC framed building by nonlinear static pushover analysis. Ali Ergun at al. [18] presents the Premodern code (1998 Turkish earthquake code) to consider the seismic performance of RC building. Ali Ruzi Ozuygur [19] evaluates the structural design of a 50-story tall reinforcement concrete residential building, which was planned to be constructed in Istanbul. Its seismic performance has been checked by nonlinear time history analysis. Leonardo Avila at al. [20] presents the seismic performance of asymmetric masonry building. Mohsen Kohrangi [21] comparison consists of sequential steps for identifying and understanding the similarities of the Key elements informed the seismic hazards models. Kristijan Kolozvari [22] evaluates the seismic performance and behavior of high rise RC coupled wall building with the help of dynamic analysis by modeling approach. M. Mosleh et al.[23] in this research two existing RC irregular building analyzed with EC 8 and purposed for co-linear analysis at different levels Global and Local. Jose Barros [24] this paper evaluates a different procedure for the structural design that gives the behaviour of frequent and rare earthquakes. A two-story school building is considered for study case. S. Malekpour at all.[25] this paper introduces the steel moment resisting frames by using three country code, Iranian, European and Japanese codes. The seismic performances of these codes are almost identical but differ for high rise building. Gang Shi at all.[26] present the paper which compares and design of steel moment resisting frame by the different country code and find that Chinese code designed steel moment resisting frame exhibit $20 \%$ to $150 \%$ larger resistance and stiffness than U.S. \& Euro code.

This paper present comparison of four seismic codes (IS1893-2002, ASCE7-10, EC8-2013, BSLJ) and find out the difference and similarities of their codes. The analysis and design should be done by the software STAAD PRO V8i. The structure designed in India should be confirmed from the Indian standards code. The seismic design requirements of Indian standards and U.S. of the structure depends upon the seismic zoning system, site classification, fundamental period, response reduction factor, important factor, story drift and base shear are given in table 1 . There are different parameter of Japan and Europe which are given table 2 . Every code provides approximate formulas for estimating the time period and calculating base shear, lateral forces, and other required parameters.

\section{Objective of Study:-}

The main purpose of this study is to bring out a detailed seismic analysis and structural design on simulation tool STAAD PRO of a rectangular plan of multi-storey building. This study is focused to carry out the advantage of seismic design of multi-storey building using different country code with STTAD PRO at global level with ease of use. This numerical study comprises of-

1. To understand the accuracy of software's for analysis and design of multi-storey building.

2. To compare the results and behaviour of structures using different country code.

\section{Simulation Tool STAAD PRO:-}

STAAD stands for Structural Analysis and Design. STAAD PRO is a general purpose structural analysis and design programme with applications primarily in the building industry-commercial buildings, bridges and highways structures etc. It was the first structural software which adopted for the analysis of matrix problems. The programme hence consists of the following facilities to enable this work. Graphical model generation utilities as well as text editor based commands for creating the mathematical model. Beam and column are represented using lines. Walls, slabs and panel type member are represents using triangular and quadrilateral finite elements. These utilities enable the users to create the geometry, assign properties, orient cross sections as desired, assign materials like steel, concrete, timber, aluminium, safety supports, and apply loads for desired loading case.

Results viewing, result verification and report generation tools for examining displacement diagrams, bending moment and shear force diagram, beam etc.

\section{Comparison of seismic provision}

The different seismic provisions and standards of different countries are shown in table in table $1 \& 2$ respectively. The factor of safety for different loading case for country code is represented in table 3 . 
International Journal of Trend in Scientific Research and Development (IJTSRD) @ www.ijtsrd.com eISSN: 2456-6470

Table 1: Comparison of seismic provisions of IS 1893-2002[5] and ASCE 7-10[2]

\begin{tabular}{|c|c|c|}
\hline Parameters & IS 1893-2002[5] & ASCE 7-10[2] \\
\hline Zoning system & $\begin{array}{l}\text { The country divided into four zones (II, III, IV, and V) } \\
\text { zone II } Z=0.10 \\
\text { zone III } Z=0.16 \\
\text { zone IV } Z=0.24 \\
\text { zone V } Z=0.36\end{array}$ & 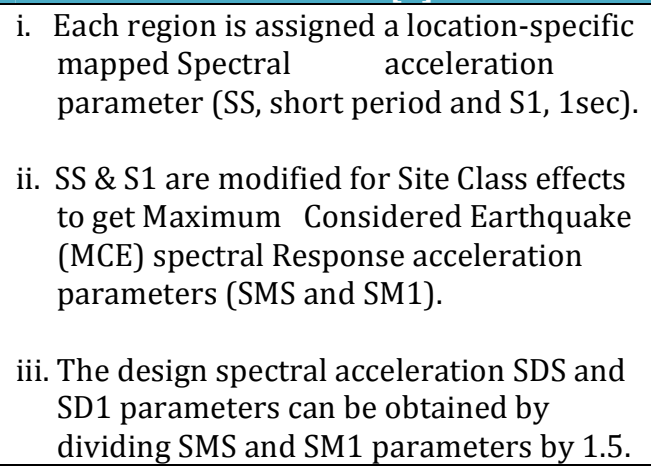 \\
\hline $\begin{array}{c}\text { Site } \\
\text { classification }\end{array}$ & $\begin{array}{l}\text { Classification of site depends upon standard } \\
\text { penetration test }(\mathrm{N}) \text {. }\end{array}$ & $\begin{array}{l}\text { Average shear wave velocity }\left(\mathrm{v}_{\mathrm{s}}\right) \text {, average } \\
\text { field standard penetration resistance }(\mathrm{n}) \text {, and } \\
\text { average undrained shear strength }\left(\mathrm{S}_{\mathrm{u}}\right) \text { for the } \\
\text { top } 30.5 \mathrm{~m} \text { are used to classify different sites. }\end{array}$ \\
\hline $\begin{array}{l}\text { Approximate } \\
\text { fundamental } \\
\text { period }\end{array}$ & $\begin{array}{l}\text { The approximate fundamental period for "Reinforced } \\
\text { Concrete Moment Resisting Frame" } \\
T_{a}=0.075 h_{n}{ }^{0.75}, h_{n} \text { in meter. }\end{array}$ & 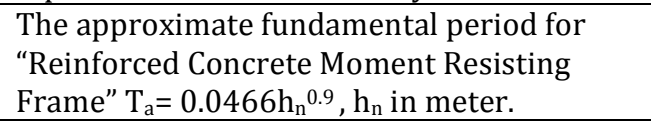 \\
\hline $\begin{array}{l}\text { Response } \\
\text { reduction } \\
\text { factor }\end{array}$ & $\begin{array}{l}\text { i. Ordinary moment resisting Frame (OMRF), } \mathrm{R}=3 \\
\text { ii. Special moment resistant Frame (SMRF), } \quad \mathrm{R}=5\end{array}$ & $\begin{array}{l}\text { i. Ordinary moment resisting Frame (OMRF), } \\
\mathrm{R}=3 \\
\text { ii. Intermediate Moment Resisting Frames } \\
\text { (IMRF) R = 5 }\end{array}$ \\
\hline $\begin{array}{l}\text { Important } \\
\text { factor }\end{array}$ & $\begin{array}{l}\text { i. Important service and community building } \mathrm{I}=1.5 \\
\text { ii. All other Buildings } \mathrm{I}=1.0\end{array}$ & $\begin{array}{l}\text { Depends upon risk categories (I, ii, iii, iv)- } \\
\text { ASCE } 7 \text { has four seismic important factor I = } \\
1.0,1.0,1.25,1.5 \text { respectively. }\end{array}$ \\
\hline Drift criteria & $\begin{array}{l}\text { Allowable "elastic story drifts are } 0.004 \mathrm{H}_{\text {story }} \text { for all } \\
\text { the structures irrespective of any structure under } \\
\text { risk category. }\end{array}$ & $\begin{array}{l}\text { Allowable "inelastic" story drifts are limited } \\
\text { to } 0.020 \mathrm{H}_{\text {story }} \text { for a commercial building } \\
\text { having risk category I or II. }\end{array}$ \\
\hline $\begin{array}{l}\text { Minimum } \\
\text { design lateral } \\
\text { force }\end{array}$ & 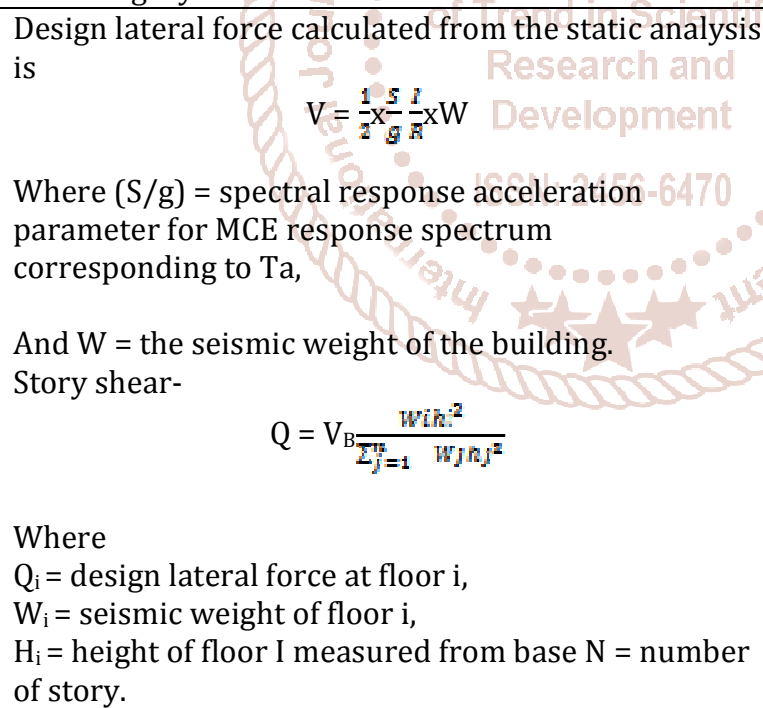 & $\begin{array}{l}\text { Design lateral force calculated from static } \\
\text { analysis is } \mathrm{V}=\mathrm{C}_{\mathrm{s}} \times \mathrm{W} \\
\text { where } \mathrm{C}_{\mathrm{s}}=\text { the seismic response coefficient } \mathrm{C}_{\mathrm{S}} \\
=\frac{S_{\mathrm{DS}}}{\frac{\pi}{V_{\mathrm{s}}}} \\
\mathrm{W}=\text { the seismic weight of the building }\end{array}$ \\
\hline $\begin{array}{l}\text { Response } \\
\text { spectrum }\end{array}$ & 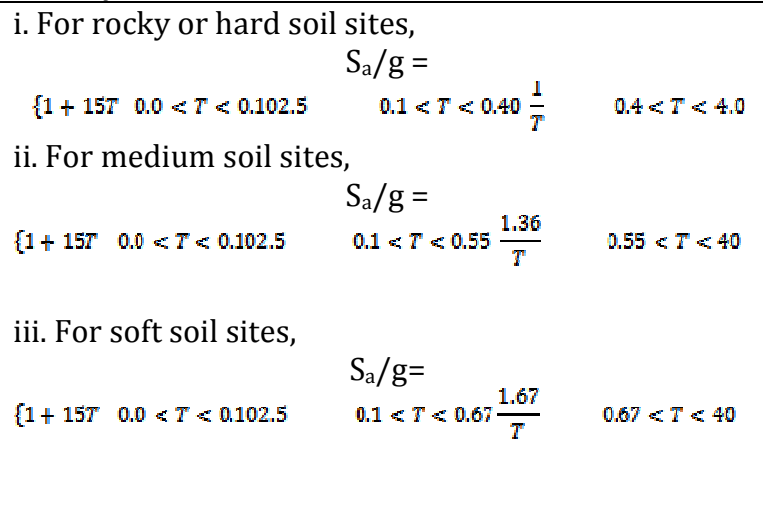 & $\begin{array}{l}\text { i. Spectral Acceleration, For } \mathrm{T}<\mathrm{T}_{0}, \\
\mathrm{Sa}=\mathrm{S}_{\mathrm{DS}}\left(0.4+0.6 \mathrm{~T} / \mathrm{T}_{0}\right) \\
\mathrm{T}_{0}=0.2 . \mathrm{S}_{\mathrm{D} 1} / \mathrm{S}_{\mathrm{DS}} \\
\text { ii. } \mathrm{T}_{0}>\mathrm{T}>\mathrm{T}_{\mathrm{S}}, \mathrm{Sa}=\mathrm{S}_{\mathrm{DS}} \text {, } \\
\mathrm{T}_{\mathrm{S}}=\mathrm{S}_{\mathrm{D} 1} / \mathrm{S}_{\mathrm{DS}} \\
\text { iii. } \mathrm{TS}>\mathrm{T}>\mathrm{TL} \text {, } \\
\quad \mathrm{Sa}=\mathrm{S}_{\mathrm{D} 1} / \mathrm{T} \\
\text { where } \mathrm{T}_{\mathrm{L}}=\text { long period OR transition period } \\
\text { iv. } \mathrm{T}>\mathrm{T}_{\mathrm{L}} \\
\text { Sa }=\mathrm{S}_{\mathrm{D} 1} \mathrm{~T}_{\mathrm{L}} / \mathrm{T}^{2}\end{array}$ \\
\hline
\end{tabular}


Table 2: Comparison of seismic provisions of EC 8 2004[26], BSLJ [6, 25]

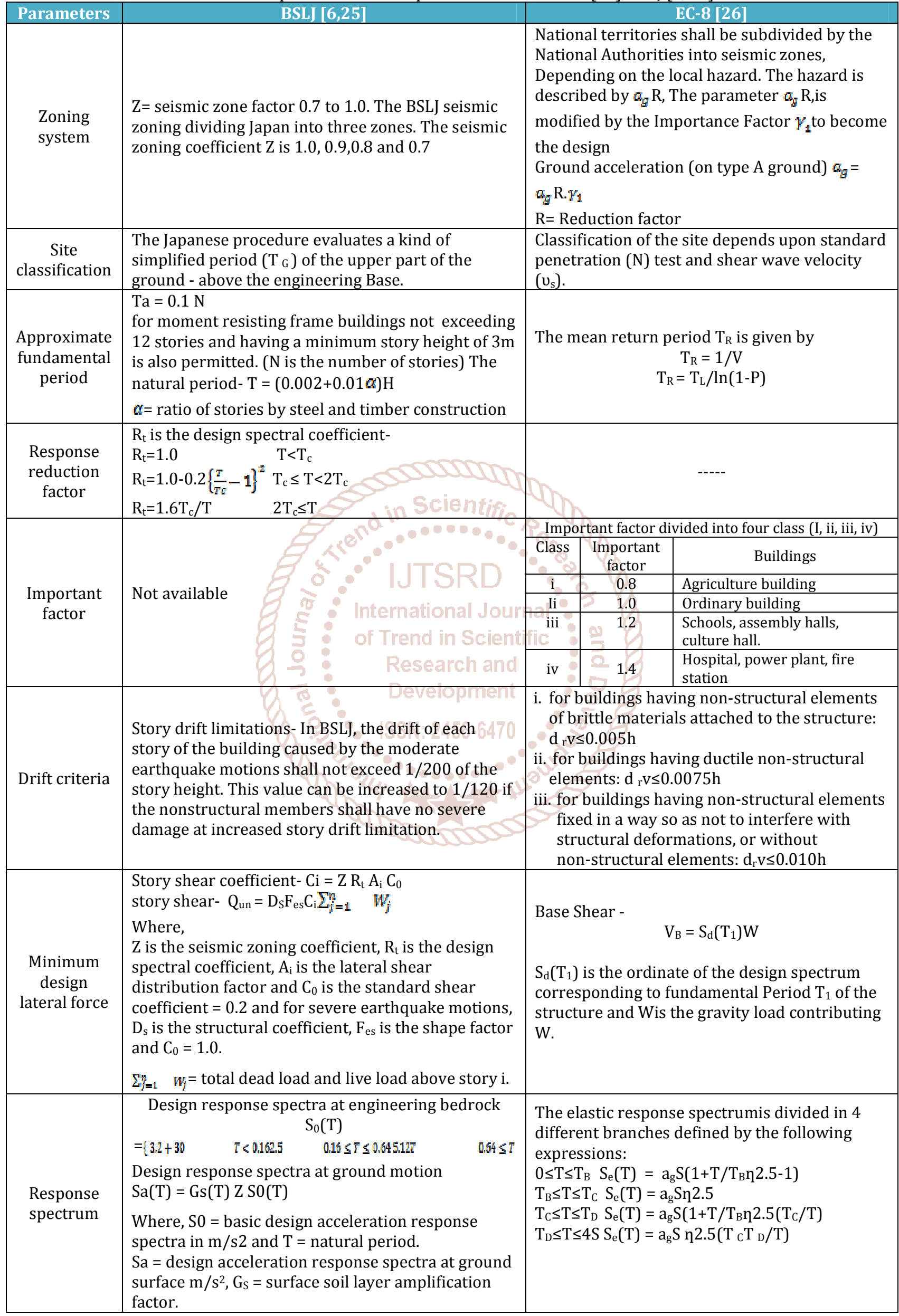


International Journal of Trend in Scientific Research and Development (IJTSRD) @ www.ijtsrd.com eISSN: 2456-6470

Table 3: Load combination of IS1893-2002, ASCE7-10, BSLJ and EC-2

\begin{tabular}{|c|c|c|c|}
\hline IS875-2002 [5] & ASCE7-10 [2] & BSL] 6,25] & EC-2 [29] \\
\hline $1.5(\mathrm{D}+\mathrm{L})$ & $1.4 \mathrm{D}$ & $\mathrm{D}+\mathrm{L}+\mathrm{E}$ & $1.35 \mathrm{D}+1.5 \mathrm{~L}$ \\
\hline $1.2(\mathrm{D}+\mathrm{L} \pm \mathrm{W})$ & $1.2 \mathrm{D}+1.6 \mathrm{~L}+0.5 \mathrm{Lr}$ & $\mathrm{D}+\mathrm{L}+\mathrm{S}+\mathrm{E}$ & $1.0 \mathrm{D}+1.5 \mathrm{~W}$ \\
\hline $1.5(\mathrm{D} \pm \mathrm{W})$ & $1.2 \mathrm{D}+1.6 \mathrm{Lr}+(\mathrm{L} 0 \mathrm{R} 0.8 \mathrm{~W})$ & & $1.35 \mathrm{D}+1.5 \mathrm{~L}+0.9 \mathrm{~W}$ \\
\hline $0.9 \mathrm{D} \pm 1.5 \mathrm{~W}$ & $1.2 \mathrm{D}+1.6 \mathrm{~W}+1.0 \mathrm{~L}+0.5 \mathrm{Lr}$ & & \\
\hline & $0.9 \mathrm{D}+1.6 \mathrm{~W}$ & & \\
\hline & $0.9 \mathrm{D}+1.0 \mathrm{~W}$ & & \\
\hline & $0.9 \mathrm{D}+1.0 \mathrm{E}$ & & \\
\hline & \multicolumn{2}{|l}{} & \\
\hline
\end{tabular}

Study Model:-

A geometrically similar 10 story included 4 -bay by 4- bay reinforcement concrete ordinary moment resting frame was considered for all the codes. The height of each story was $3 \mathrm{~m}$ and a total height of $30 \mathrm{~m}$. The width and length of the structure were 24 and $24 \mathrm{~m}$ respectively. The selected building was to represent an office building. The D.L. per unit area of the floor, consisting of the floor slab finishes etc. is $4 \mathrm{KN} / \mathrm{m} 2$. The weight of the partition on the floor can be assumed to be $2 \mathrm{KN} / \mathrm{m} 2$. The intensity of live load on each floor is $3 \mathrm{KN} / \mathrm{m}^{2}$ and on the roof are $1.5 \mathrm{KN} / \mathrm{m}^{2}$. The soil below the foundation is hard and the building is located in Delhi. The plan area is given in figure $1 \& 2$. The 3-D structural model is shown in figure 3. The site soil classification and the response acceleration parameters and zone factor for this building are shown in Table 4.

The load combination of dead load, live load, roof load and earthquake load, wind load for their four building code are given in Table 3.

\section{Building parameter-}

Size of beam $=300 \times 600 \mathrm{~mm}$

Size of column $=650 \times 450 \mathrm{~mm}$

Size of building $=24 \times 24 \mathrm{~mm}$

D.L. of slab including finishes $4 \mathrm{KN} / \mathrm{m} 2$

The weight of partition on floor $2 \mathrm{KN} / \mathrm{m} 2$

L.L. of each floor $=3 \mathrm{KN} / \mathrm{m} 2$

L.L. on the roof $=1.5 \mathrm{KN} / \mathrm{m} 2$

Soil below foundation is hard soil

Table 4 Site location and classification of seismic Design parameters

\begin{tabular}{|c|l|c|}
\hline Code & Zone coefficient $/$ response acceleration parameters & Site class \\
\hline IS1893 & Seismic zone: iv, $(\mathrm{z})=0.24$ Importance factor $(\mathrm{I})=1 \mathrm{~T}=0.96 \mathrm{~s}$ & Type 2 (hard soil) \\
\hline ASCE7-10 & Spectrum response acceleration $\mathrm{Ss}=1.893, \mathrm{~S} 1=0.85$, & Site class D (stiff soil) \\
\hline BSLJ & Seismic zone: $\mathrm{iv},(\mathrm{z})=0.75 \mathrm{Ta}=0.1 \mathrm{~N} \mathrm{sec}, \mathrm{a}=1$ & Soil type C \\
\hline EC-8 & Seismic zone: iii $\mathrm{ag}=0.15 \mathrm{~g}$ Importance factor $(\gamma)=1$ & \\
\hline
\end{tabular}

\section{Seismic weight-}

Floor area $=24 \times 24=576$

Dead load $=4 \mathrm{KN} / \mathrm{m} 2$

Weight of partitions $=2 \mathrm{kN} / \mathrm{m} 2$

For live load up to and including $=3 \mathrm{KN} / \mathrm{m} 2$

Percentage of live load to be considered $=2.5 \%$

Effective weight at each floor except the roof $=4.0+2.0+0.25+3$

$$
=6.75 \mathrm{KN} / \mathrm{m} 2
$$

And at the roof $=4.0 \mathrm{KN} / \mathrm{m} 2$

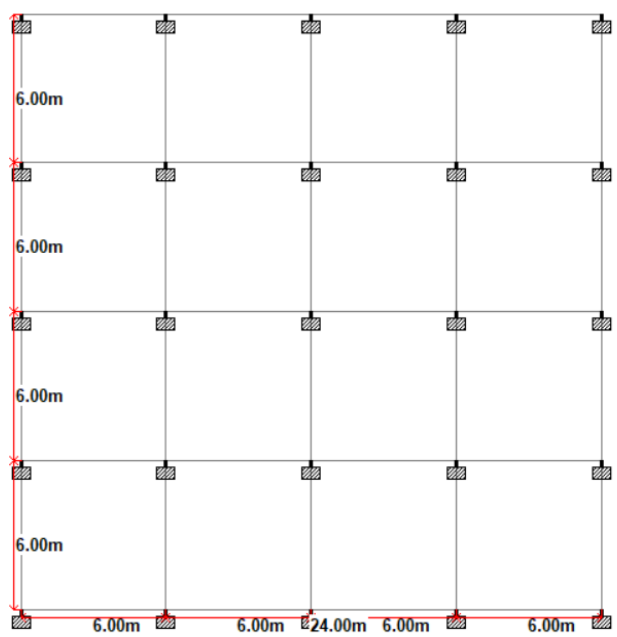

Fig.1. $4 @ 6.00 \mathrm{~m}=24 \mathrm{~m}$ plan view of the structure 


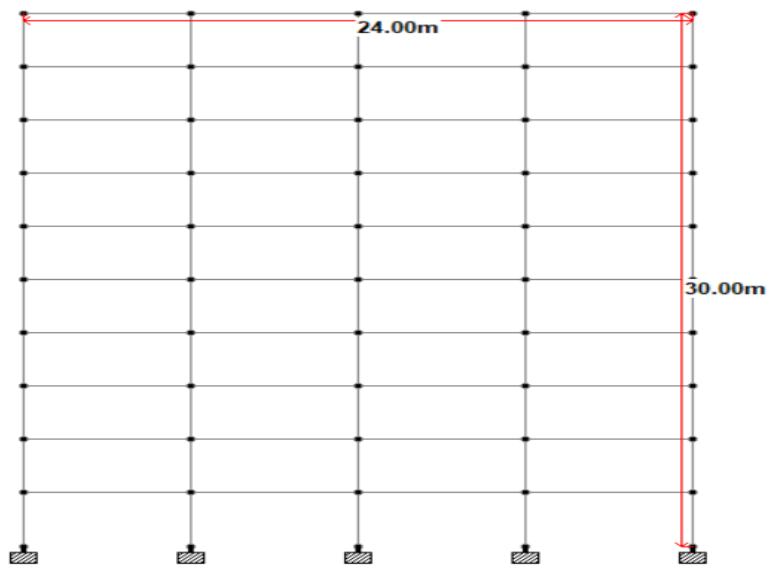

Fig.2. Front view of the structure

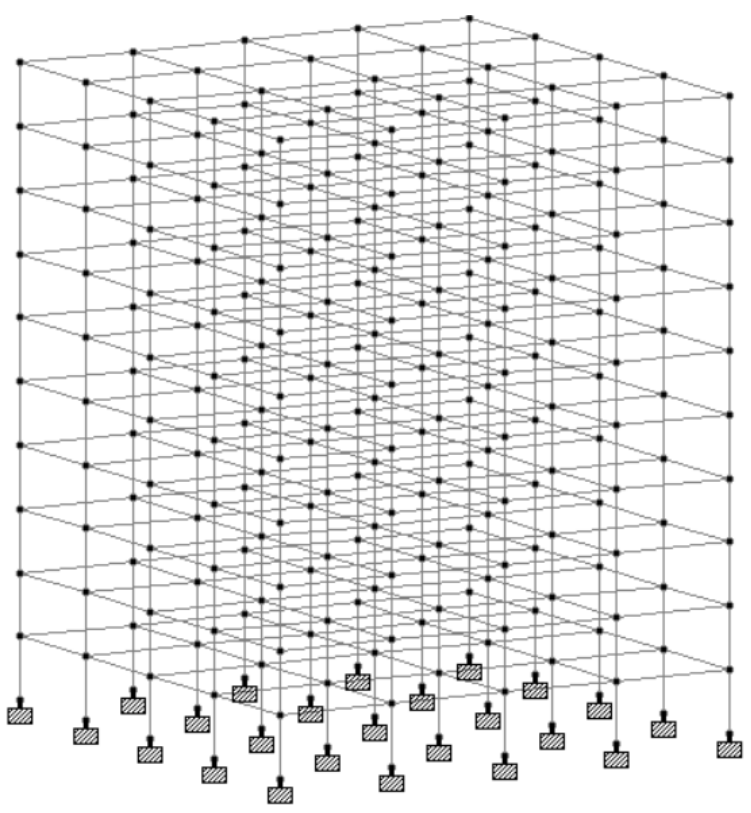

Fig.3. 3-D Structural Model of the structure

\section{Modelling and design of the structure for analysis:-}

The building should be consisting of three-dimensionally in the office purpose. Analysis, and design on software STAAD.pro V8 i. The column was considered as fixed support. Dead load, live load, and seismic load considered as per their code.

Code used for concrete design- IS45 -2002, ACI 318-2008, AIJ \& EC-2

Code used for Seismic design- IS1893-2002, BS-8110, IBC-2006 \& Japanese code.

*The code BS-8110 is used for seismic design of European code on Staad- pro V8i.

*The code IBC-2006 is used for seismic design of American code on Staad- pro V8i.

The specification used for concrete design-

A grade of concrete $-30 \mathrm{MPa}$

Grade reinforcement - $415 \mathrm{MPa}$

Concrete cover of the beam - $25 \mathrm{~mm}$

Concrete cover of the column- $40 \mathrm{~mm}$

\section{Results and discussion-}

1. The analysis and design of beam, column and storey drift at different level according to IS loading condition is evaluated in the terms of maximum axial force, maximum bending moment, maximum shear force, story drift and displacement as shown in Table 5,6 \& 7. The graphical representation of the results is shown in figure from 4 to 11.

Table 5: Analysis of beam as per IS loading with different code

\begin{tabular}{|c|c|c|c|}
\hline Code & Maximum axial force (kN) & Maximum Bending moment (kNm) & Maximum shear force (kN) \\
\hline IS1893 & $111.384(1.5 \mathrm{DL}+\mathrm{LL})$ & $252.542(1.5 \mathrm{DL}+\mathrm{LL})$ & $252.083(1.5 \mathrm{DL}+\mathrm{EQX})$ \\
\hline EC-8 & $111.384(1.5 \mathrm{DL}+\mathrm{LL})$ & $252.542(1.5 \mathrm{DL}+\mathrm{LL})$ & $511.187(1.5 \mathrm{DL}+\mathrm{EQX})$ \\
\hline ASCE & $110.9(1.5 \mathrm{DL}+\mathrm{EQX})$ & $233.25(1.5 \mathrm{DL}+\mathrm{EQX})$ & $505.186(1.5 \mathrm{DL}+\mathrm{LL})$ \\
\hline BSLJ & $92.398(1.5 \mathrm{DL}+\mathrm{LL})$ & $233.25(1.5 \mathrm{DL}+\mathrm{LL})$ & $162.564(1.5 \mathrm{DL}+\mathrm{LL})$ \\
\hline
\end{tabular}




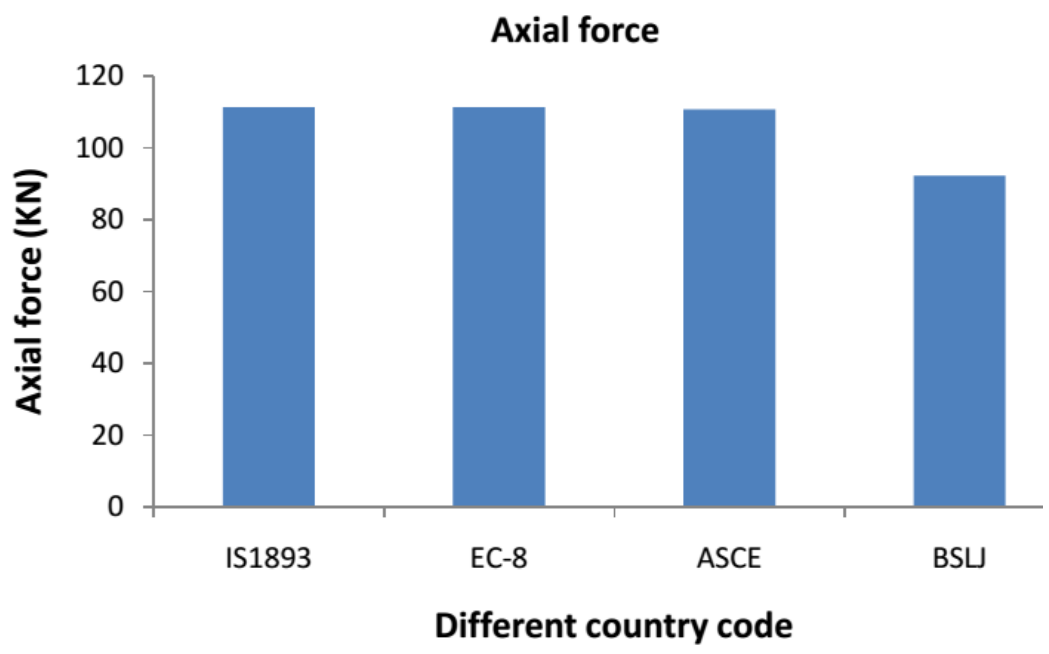

Fig.4. Axial force as per different code

\section{Shear force}

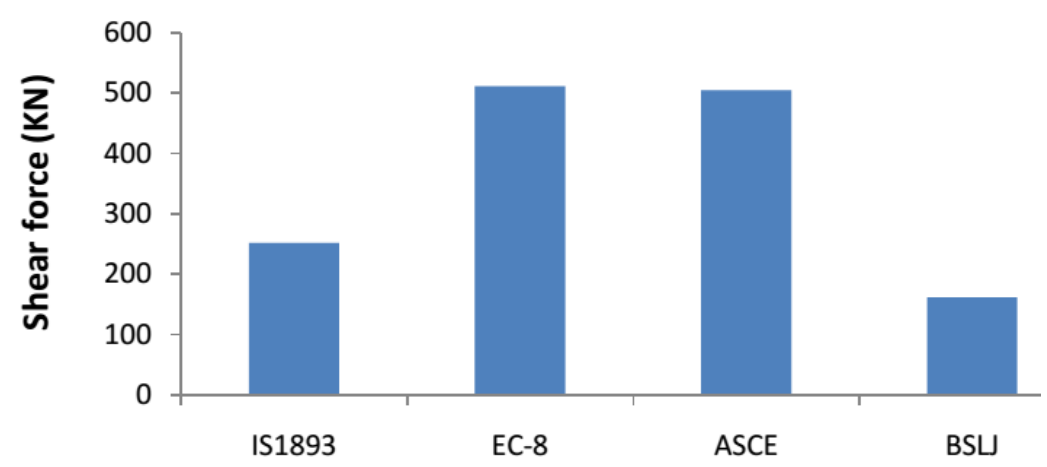

Different country code

Fig.5. Bending moment as per different code

\section{Shear force}

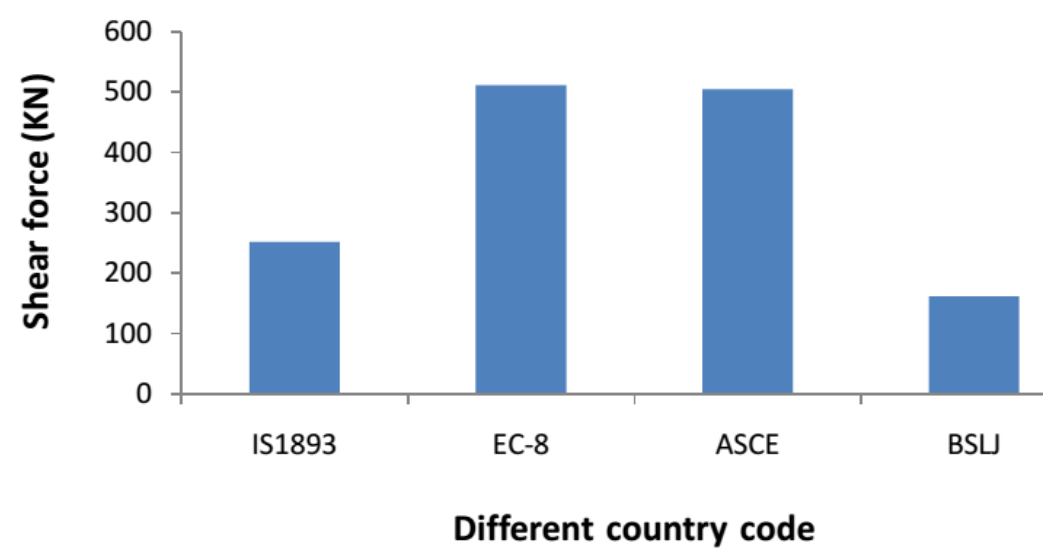

Fig.6. Shear force with different code

Analysis of beam in table 5 as per IS loading and its graphical results shows that the value of maximum axial force in beam is max for IS and EC but the min for BSLJ. The value of bending moment in beam is max for also IS and EC as compared to ASCE \& BSLJ. The value of shear force in beam is max for EC but min for BSLJ.

Table 6: Analysis of column as per IS loading with different code

\begin{tabular}{|c|c|c|c|c|}
\hline Code & $\begin{array}{c}\text { Maximum axial force } \\
(\mathrm{kN})\end{array}$ & $\begin{array}{c}\text { Maximum Bending moment } \\
(\mathrm{KNm})\end{array}$ & $\begin{array}{c}\text { Maximum shear force } \\
(\mathrm{kN})\end{array}$ & $\begin{array}{c}\text { Base shear } \\
(\mathrm{kN})\end{array}$ \\
\hline IS1893 & $5358.35(1.5 \mathrm{DL}+\mathrm{LL})$ & $487.852(1.5 \mathrm{DL}+\mathrm{EQZ})$ & $285.706(1.5 \mathrm{DL}+\mathrm{EQZ})$ & 4294.75 \\
\hline EC-8 & $4781.278(1.5 \mathrm{DL}+\mathrm{LL})$ & $1065.58(1.5 \mathrm{DL}+\mathrm{EQX})$ & $684.447(1.5 \mathrm{DL}+\mathrm{EQX})$ & 4294.75 \\
\hline ASCE & $5446.855(1.5 \mathrm{DL}+\mathrm{LL})$ & $1387.759(1.5 \mathrm{DL}+\mathrm{EQX})$ & $784.251(1.5 \mathrm{DL}-\mathrm{EQX})$ & 4124.012 \\
\hline BSLJ & $5446.856(1.5 \mathrm{DL}+\mathrm{LL})$ & $202.681(1.5 \mathrm{DL}+\mathrm{EQZ})$ & $94.047(1.5 \mathrm{DL}+\mathrm{EQZ})$ & 4294.75 \\
\hline
\end{tabular}




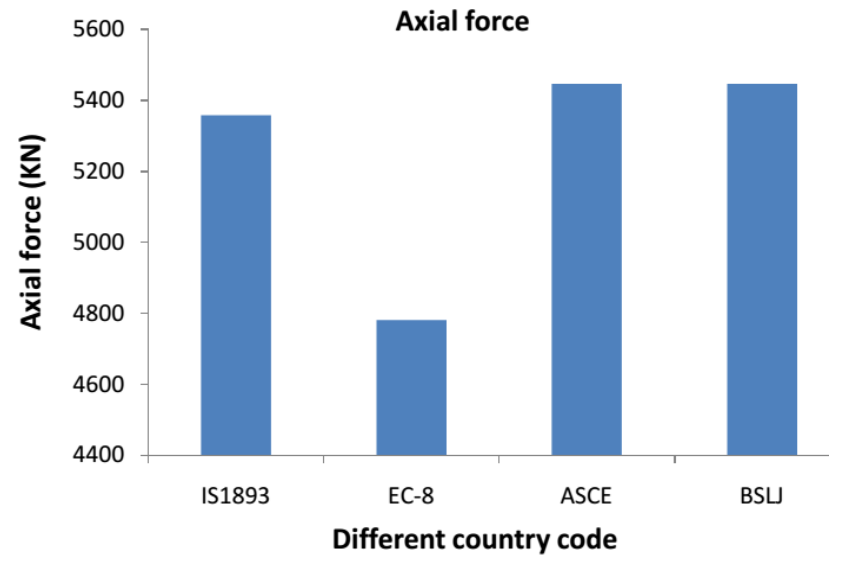

Fig.7. Axial force as per different code

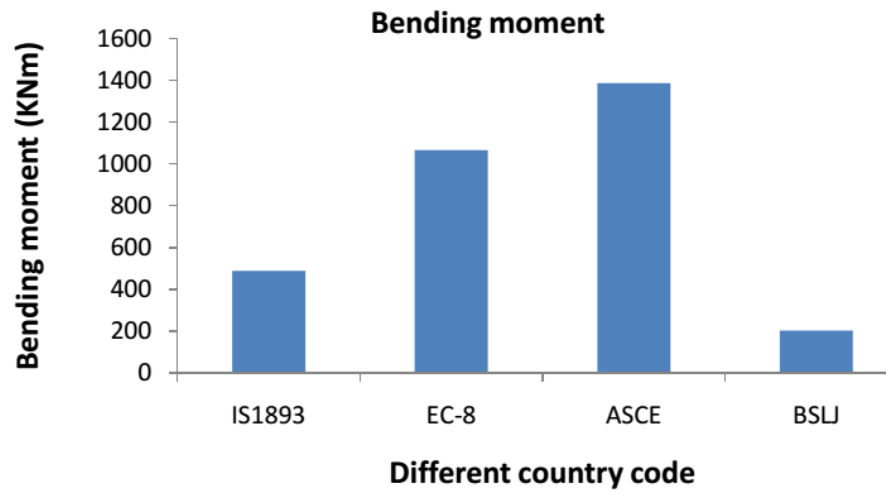

Fig.8. Bending moment as per different code

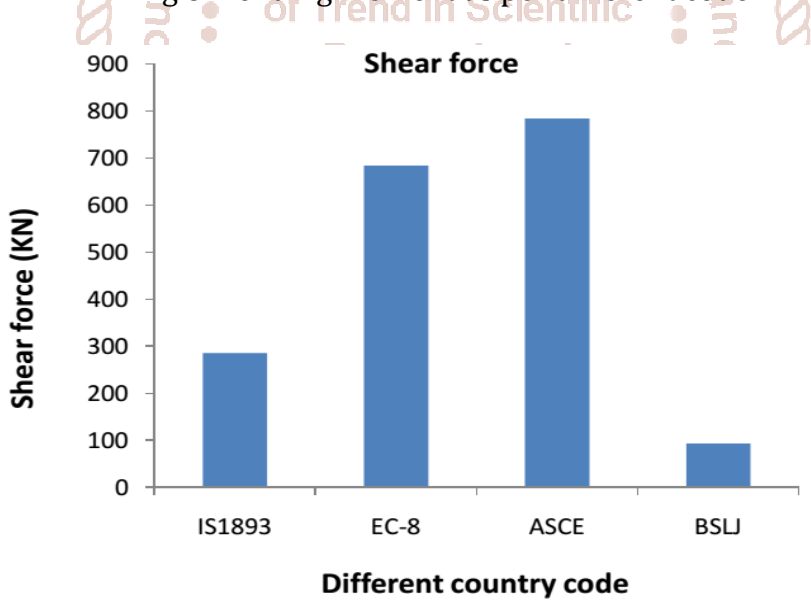

Fig.9. Shear force as per different code

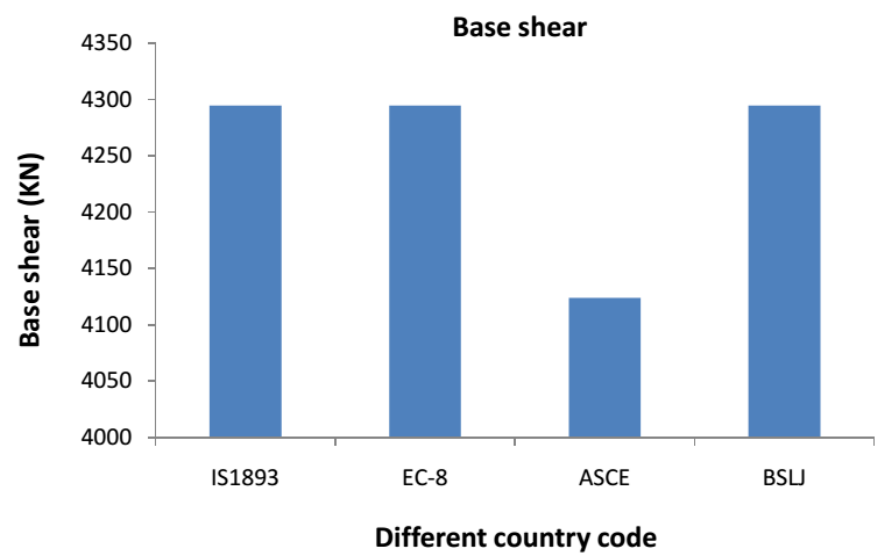

Fig.10. Base shear as per different code 
International Journal of Trend in Scientific Research and Development (IJTSRD) @ www.ijtsrd.com eISSN: 2456-6470

Analysis of column in table 6 as per IS loading and its graphical results shows that the value of maximum axial force in column is max for ASCE \& BSLJ but the min for EC. The value of bending moment in column is max for ASCE but min for BSLJ. The value of shear force in column is max for ASCE but min for BSLJ. The value of base shear is max for IS, BSLJ and EC but min for ASCE.

Table 7: Story drift and Displacement of building as per IS loading with different code

\begin{tabular}{|c|c|c|c|c|c|c|c|c|}
\hline \multirow{2}{*}{ Height in m } & \multicolumn{3}{|c|}{ IS1893 } & \multicolumn{3}{|c|}{ EC } & \multicolumn{3}{c|}{ BSLJ } \\
\cline { 2 - 10 } & Drift & Displacement & Drift & Displacement & Drift & Displacement & Drift & Displacement \\
\hline 3 & 0.9688 & 9.688 & 0.7586 & 0.7586 & 2.6013 & 2.6013 & 0.6915 & 0.6915 \\
\hline 6 & 1.5244 & 2.4932 & 1.1780 & 1.9366 & 4.0372 & 6.6385 & 1.0564 & 1.7479 \\
\hline 9 & 1.6076 & 4.1008 & 1.2096 & 3.1462 & 4.1405 & 10.7791 & 1.0662 & 2.8141 \\
\hline 12 & 1.6140 & 5.7147 & 1.1643 & 4.3106 & 3.9770 & 14.7561 & 1.0119 & 3.8261 \\
\hline 15 & 1.5976 & 7.3123 & 1.0850 & 5.3955 & 3.6936 & 18.4497 & 0.9347 & 4.7608 \\
\hline 18 & 1.5634 & 8.8757 & 0.9767 & 6.3722 & 3.3078 & 21.7575 & 0.8400 & 5.6007 \\
\hline 21 & 1.5094 & 10.3851 & 0.8394 & 7.2117 & 2.8190 & 24.5764 & 0.7274 & 6.3281 \\
\hline 24 & 1.4305 & 11.8157 & 0.6727 & 7.8843 & 2.2258 & 26.8023 & 0.5950 & 6.9232 \\
\hline 27 & 1.3096 & 13.1253 & 0.4780 & 8.3623 & 1.5365 & 28.3388 & 0.4393 & 7.3625 \\
\hline 30 & 1.0541 & 14.1794 & 0.2730 & 8.6354 & 0.8296 & 29.168 & 0.2644 & 7.6269 \\
\hline
\end{tabular}

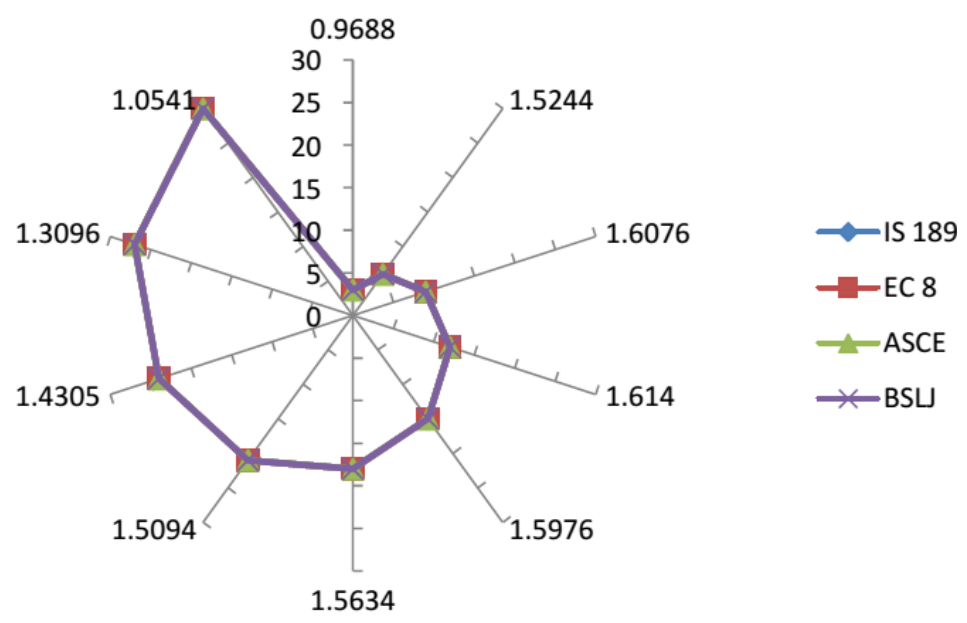

Fig.11. Value of drift at different level as per IS loading for different code

The above table and figure shows that the variation of storey drifts and displacement varies according to height of building. It is clearly shown in table that the value of drift is increasing slightly and then decreases.

2. The analysis and design of beam, column and storey drift at different level according to their loading condition is evaluated in the terms of maximum axial force, maximum bending moment, maximum shear force, story drift and displacement as shown in Table 8, 9 \& 10. The graphical representation of the results is shown in figure from 12 to 19.

Table 8: Analysis of Beam as per their code loading

\begin{tabular}{|c|c|c|c|}
\hline Code & Maximum Axial Force (kN) & Maximum Bending moment (KNm) & Maximum shear force (kN) \\
\hline IS1893 & $111.384(1.5 \mathrm{DL}+\mathrm{LL})$ & $252.542(1.5 \mathrm{DL}+\mathrm{LL})$ & $252.083(1.5 \mathrm{DL}+\mathrm{EQX})$ \\
\hline EC-8 & $141.976(1.4 \mathrm{DL}+1.6 \mathrm{LL}+1.6 \mathrm{RFL})$ & $331.976(1.4 \mathrm{DL}+1.6 \mathrm{LL}+1.6 \mathrm{RFL})$ & $240.174(1.4 \mathrm{DL}+1.6 \mathrm{LL}+1.6 \mathrm{RFL})$ \\
\hline ASCE & $122.556(1.2 \mathrm{DL}+\mathrm{LL}+1.6 \mathrm{RFL})$ & $282.111(1.2 \mathrm{DL}+\mathrm{LL}+1.6 \mathrm{RFL})$ & $493.048(1.2 \mathrm{DL}+\mathrm{LL}+\mathrm{RFL})$ \\
\hline BSLJ & 76.007 (DL+LL+EQX) & $168.362(\mathrm{DL}+\mathrm{LL}+\mathrm{EQX})$ & 132.855 (DL+LL+RFL+EQX) \\
\hline
\end{tabular}

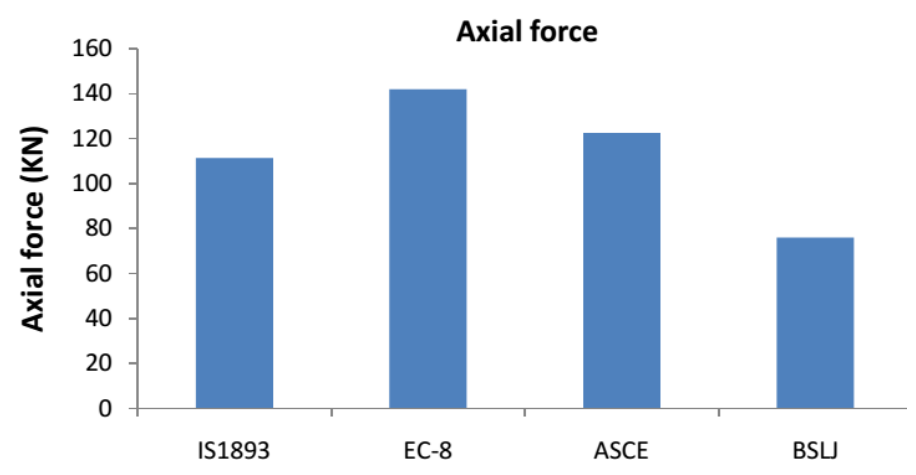

Different country code

Fig.12. Axial force as per different code 


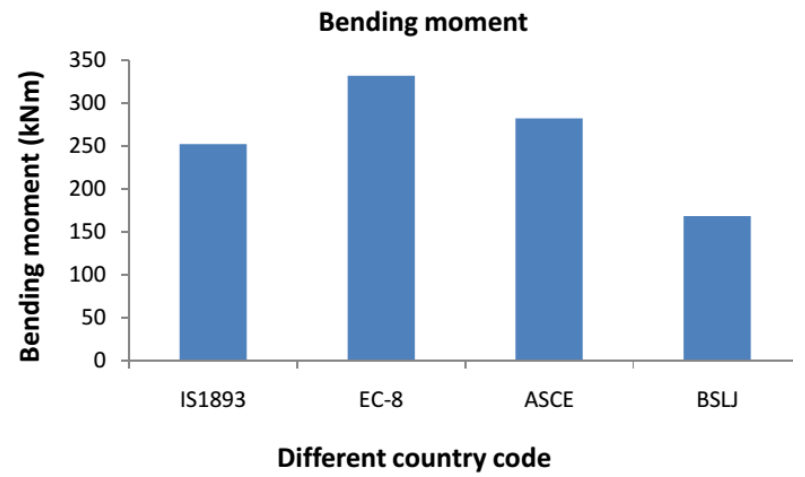

Fig.13. Bending moment as per different code

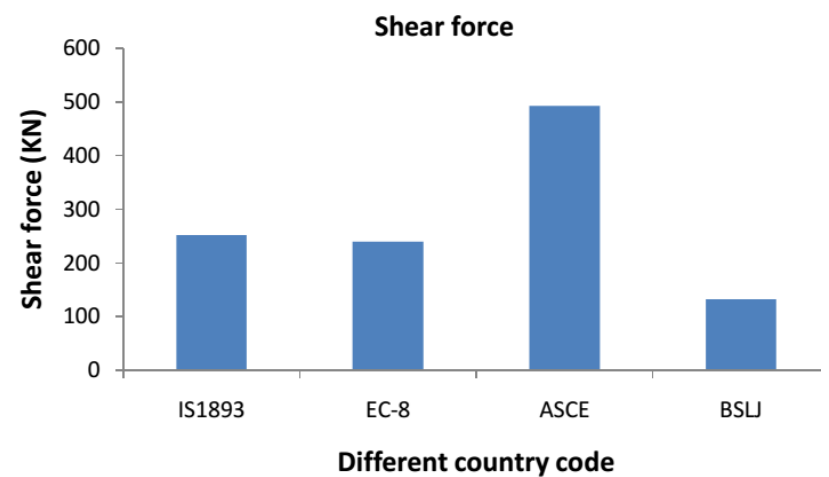

Fig.14. Shear force as per different code

Analysis of beam in table 8 as per their loading and its graphical results shows that the value of maximum axial force in beam is max for EC but the min for BSLJ. The value of bending moment in beam is max for EC but min for BSLJ. The value of shear force in beam is max for ASCE but min for BSLJ.

Table 9: Analysis of Column as per their loading condition

\begin{tabular}{|c|c|c|c|c|}
\hline Code & $\begin{array}{l}\text { Maximum axial force } \\
\text { (KN) }\end{array}$ & $\begin{array}{c}\text { Maximum Bending moment (KN- } \\
\mathrm{m} \text { ) }\end{array}$ & $\begin{array}{c}\text { Maximum shear force } \\
\text { (KN) }\end{array}$ & $\begin{array}{l}\text { Base shear } \\
\text { (KN) }\end{array}$ \\
\hline IS1893 & 5358.35 (1.5DL+LL) & $487.852(1.5 \mathrm{DL}+\mathrm{EQZ}) 7 \cap$ & 285.706 (1.5DL+EQZ) & 4294.75 \\
\hline EC-8 & $4781.278(1.5 \mathrm{DL}+\mathrm{LL})$ & $1065.58(1.5 \mathrm{DL}+\mathrm{EQX})$ & 684.447 (1.5DL+EQX) & 4294.75 \\
\hline ASCE & 5446.855 (1.5DL+LL) & 1387.759(1.5DL+EQX) & 784.251 (1.5DL-EQX) & 4124.012 \\
\hline BSLJ & 5446.856 (1.5DL+LL) & $202.681(1.5 \mathrm{DL}+\mathrm{EQZ})$ & 94.047 (1.5DL+EQZ) & 4294.75 \\
\hline
\end{tabular}

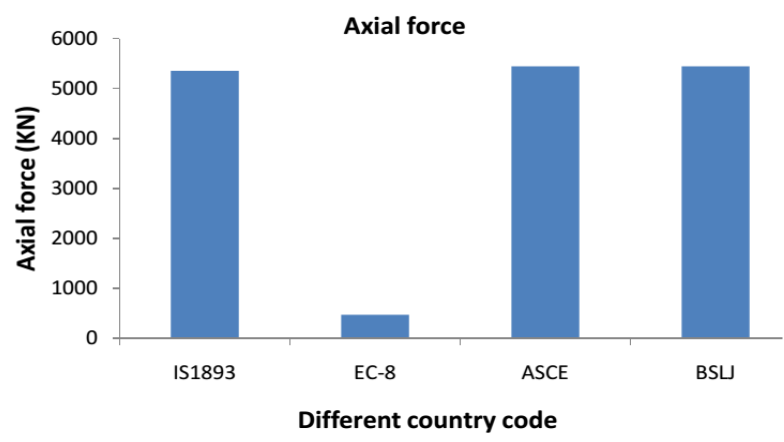

Fig.15. Axial force with different code

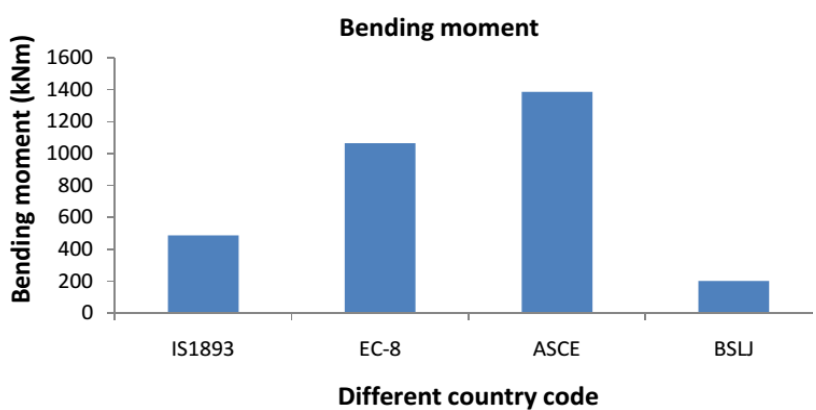

Fig.16. Bending moment as per different code 


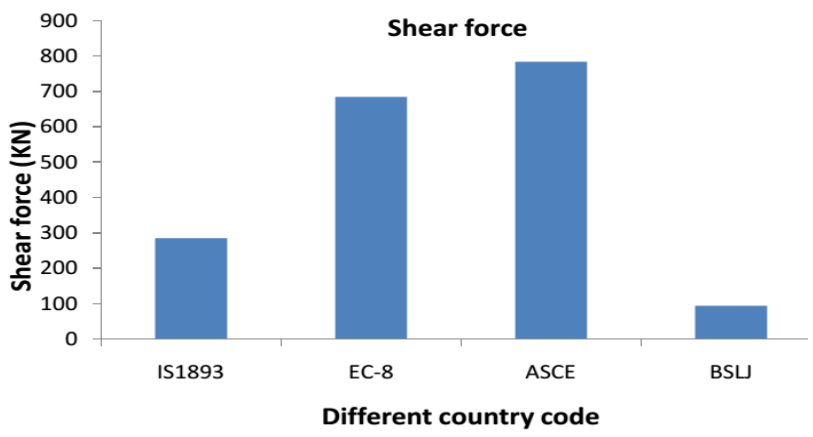

Fig.17. Shear force as per different code

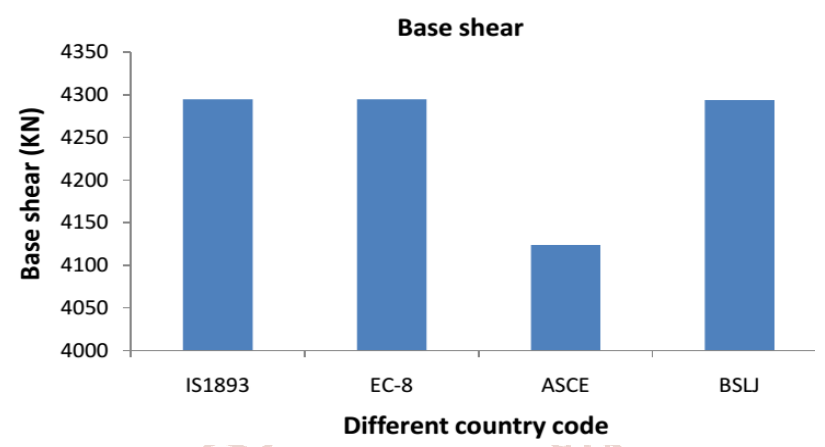

Fig.18. Base shear as per different code

Analysis of column in table 9 as per their loading and its graphical results shows that the value of maximum axial force in column is max for ASCE and BSLJ but the min for EC-8. The value of bending moment in column is max for ASCE but min for BSLJ. The value of shear force in column is max for ASCE but min for BSLJ. The value of base shear is max for IS, BSLJ and EC but min for ASCE.

Table 10: Story drift and Displacement of building as per their code loading

\begin{tabular}{|c|c|c|c|c|c|c|c|c|}
\hline \multirow{2}{*}{$\begin{array}{l}\text { Height } \\
\text { in } \mathrm{m}\end{array}$} & \multicolumn{2}{|c|}{ IS1893 } & \multicolumn{2}{|r|}{ EC-8 } & \multicolumn{2}{|r|}{ ASCE } & \multicolumn{2}{|r|}{ BSLJ } \\
\hline & Drift & Displacement & Drift & Displacement & Drift & Displacement & Drift & Displacement \\
\hline 3 & 0.9688 & 9.688 & 0.9688 & 9.688 & 2.6931 & 2.6931 & 0.3112 & ............. \\
\hline 6 & 1.5244 & 2.4932 & 1.5244 & 2.4932 & 4.1963 & 6.8894 & 0.7865 & ........... \\
\hline 9 & 1.6076 & 4.1008 & 1.6076 & 4.1008 & 4.3324 & 11.2218 & 1.2664 & ............ \\
\hline 12 & 1.6140 & 5.7147 & 1.6140 & 5.7147 & 4.1968 & 15.4186 & 1.7217 & ............. \\
\hline 15 & 1.5976 & 7.3123 & 1.5976 & 7.3123 & 3.9353 & 19.3539 & 2.1423 & ............ \\
\hline 18 & 1.5634 & 8.8757 & 1.5634 & 8.8757 & 3.5601 & 22.9140 & 2.5203 & ............. \\
\hline 21 & 1.5094 & 10.3851 & 1.5094 & 10.3851 & 3.0651 & 25.9791 & 2.2781 & .............. \\
\hline 24 & 1.4305 & 11.8157 & 1.4305 & 11.8157 & 2.4444 & 28.4235 & 3.1154 & ............... \\
\hline 27 & 1.3096 & 13.1253 & 1.3096 & 13.1253 & 1.7025 & 30.1260 & 3.3131 & ............. \\
\hline 30 & 1.0541 & 14.1794 & 1.0541 & 14.1794 & 0.964 & 31.055 & 3.4321 & $\ldots+\ldots$ \\
\hline
\end{tabular}

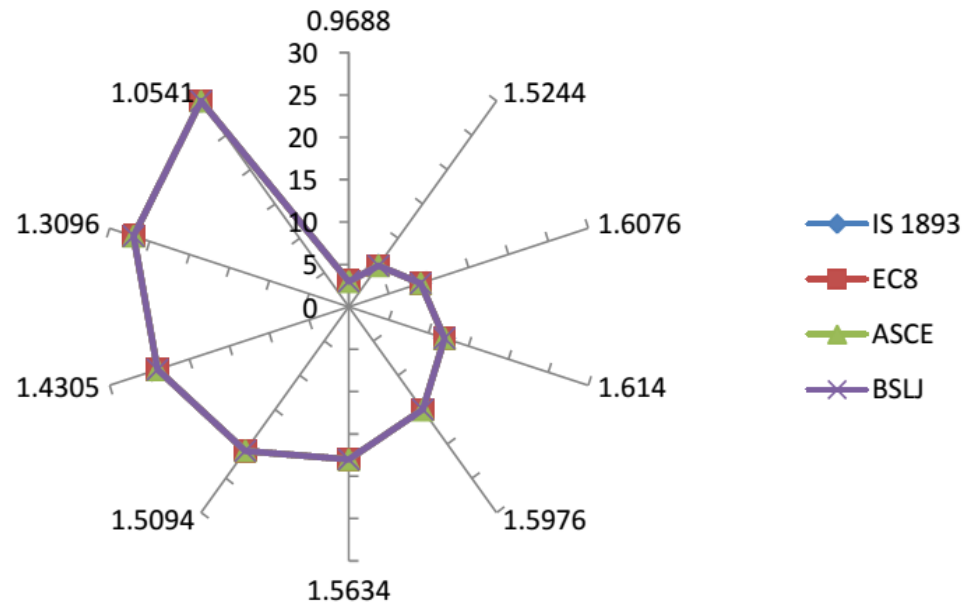

Fig.19. Value of drift as different code

The above table and figure shows that the variation of storey drifts and displacement varies according to height of building. It is clearly shown in table that the value of drift is increasing slightly and then decreases. 
3. Now the concrete design of beam and column according to IS loading condition is evaluated in the terms of required area and percentage of steel as shown in Table $11 \& 12$. The graphical representation of the results is shown in figure from 20 to 23.

Table 11: Concrete design of beam as per IS code loading

\begin{tabular}{|c|c|c|}
\hline Code & Required area & Percentage of steel \\
\hline IS456 & 4061.970 & 1.76 \\
\hline EC-2 & 4321.083 & 1.10 \\
\hline ACI & 4452.23 & 1.29 \\
\hline AIJ & 4224.11 & 1.02 \\
\hline
\end{tabular}

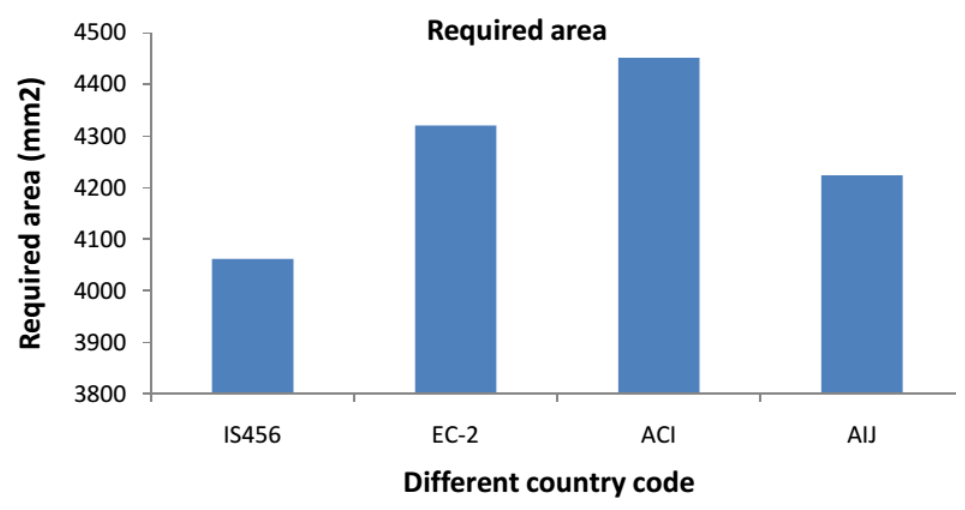

Fig.20. Required area as per different code

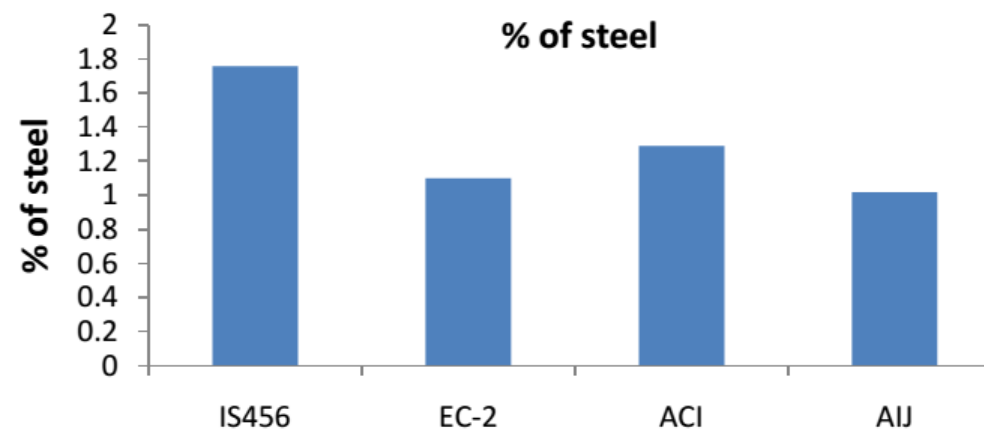

Different country code

Fig.21. Percentage of steel as per different code

The concrete design of beam in table 11 as per IS loading condition and its graphical results shows that the value of required area in beam is max for ACI but the min for IS. The value of \% steel in beam is max for IS but min for AIJ.

Table 12: Concrete design of column as per IS code loading

\begin{tabular}{|c|c|c|c|c|}
\hline 0.1 & Main reinforcement & Tie reinforcement & Required area $\left(\mathrm{mm}^{2}\right)$ & Percentage of steel (\%) \\
\hline IS456 & $24 \# 20 \emptyset$ & $8 \mathrm{~mm} @ 300 \mathrm{~mm} \mathrm{c} / \mathrm{c}$ & 7539.82 & 2.58 \\
\hline EC-2 & $36 \# 25 \emptyset$ & $8 \mathrm{~mm} @ 180 \mathrm{~mm} \mathrm{c} / \mathrm{c}$ & 9754 & 3.219 \\
\hline ACI & $12 \# 32 \emptyset$ & $12 \mathrm{~mm} @ 110 \mathrm{~mm} \mathrm{c} / \mathrm{c}$ & 8862.8 & 0.528 \\
\hline AIJ & $12 \# 13 \emptyset$ & $10 \mathrm{~mm} @ 320 \mathrm{~mm} \mathrm{c} / \mathrm{c}$ & 1470.265 & 3.299 \\
\hline
\end{tabular}

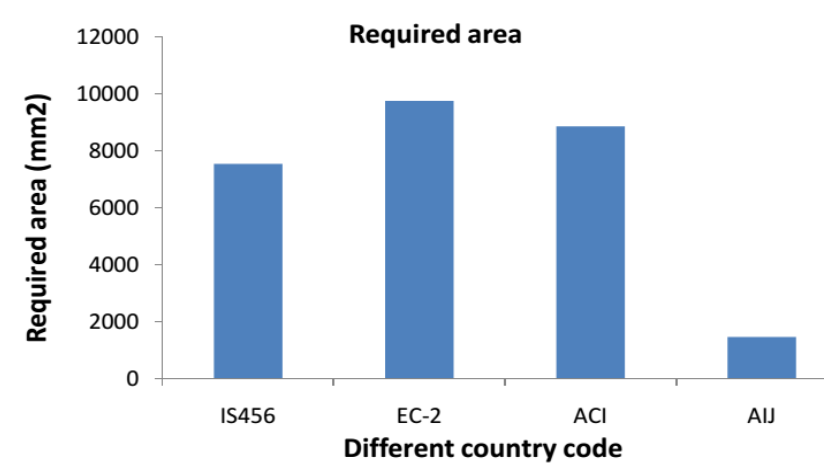

Fig.22. Required area as per different code 


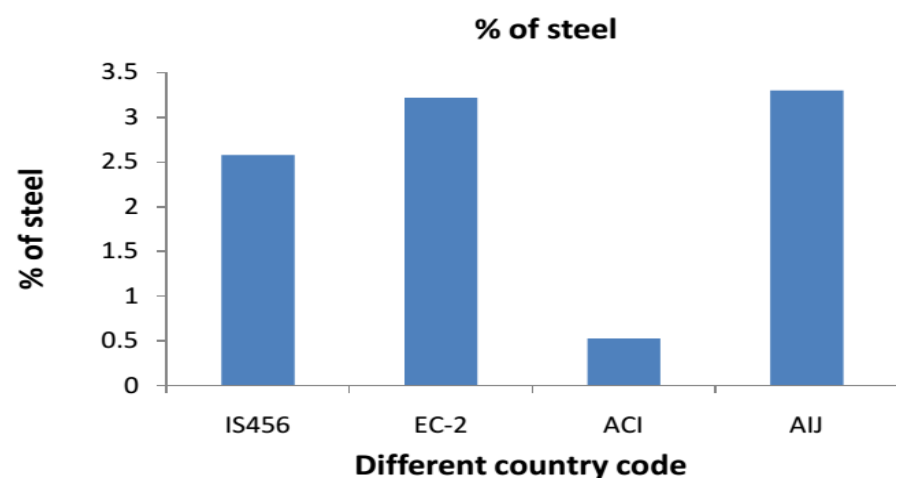

Fig.23. \% of steel as per different code

The concrete design of column in table 12 as per IS loading condition and its graphical results shows that the value of required area in column is max for EC but the min for AIJ. The value of \% steel in column is max for AIJ but min for ACI.

4. Now the concrete design of beam and column according to their loading condition is evaluated in the terms of required area and percentage of steel as shown in Table $13 \& 14$. The graphical representation of the results is shown in figure from 24 to 27.

Table 13: Concrete design of beam according as per their code loading

\begin{tabular}{|c|c|c|}
\hline Code & Required area & Percentage of steel \\
\hline IS456 & 4061.970 & 1.76 \\
\hline EC-2 & 2033 & 1.10 \\
\hline ACI & 493.048 & 1.19 \\
\hline AIJ & 223.19 & 1.02 \\
\hline
\end{tabular}

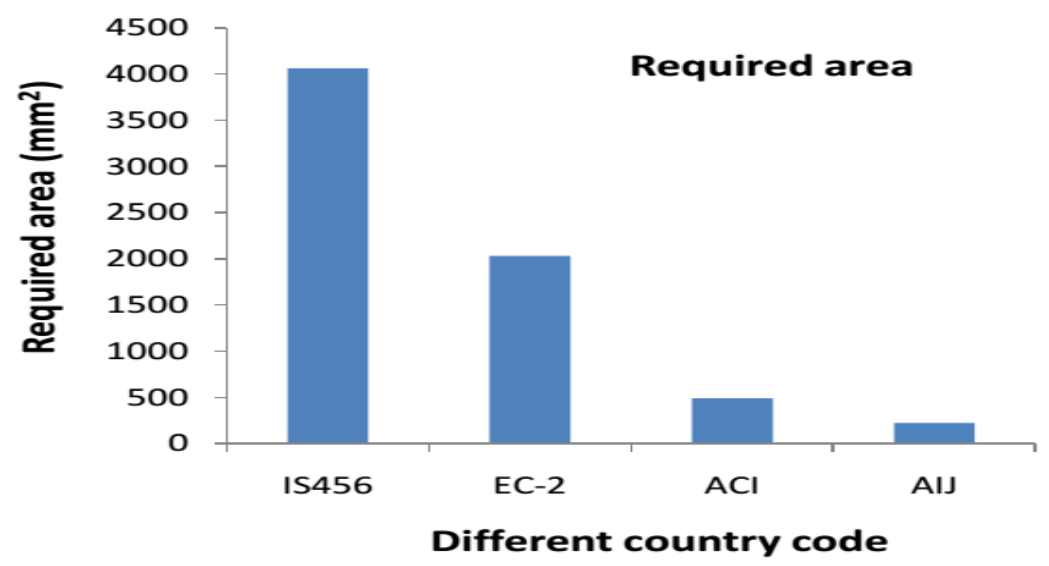

Fig.24. Required area as per different code

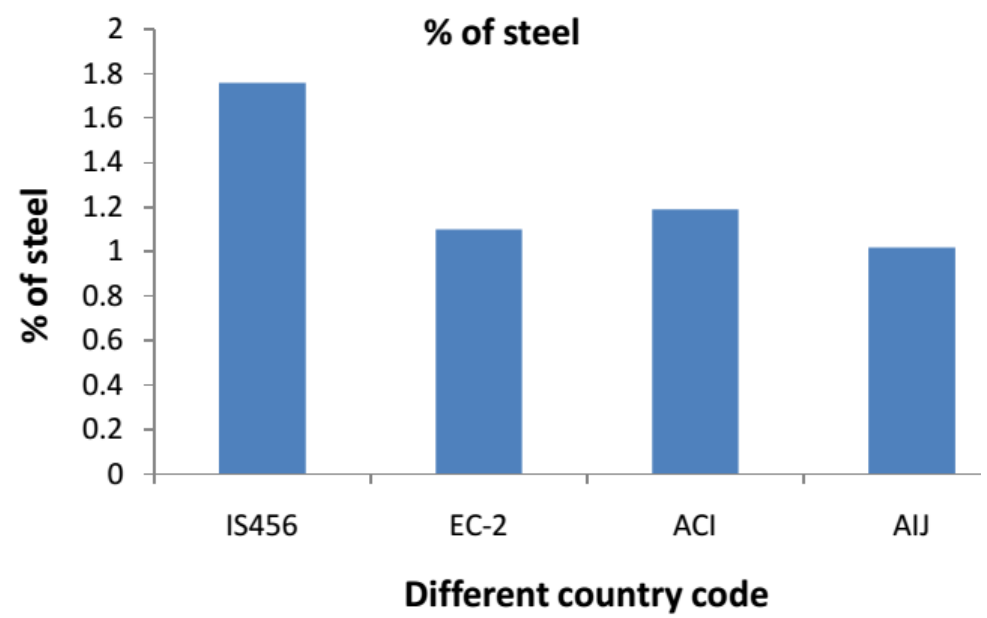

Fig.25. \% of steel with different code

The concrete design of beam in table 13 as per their loading condition and its graphical results shows that the value of required area in beam is max for IS but the min for AIJ. The value of \% steel in beam is max for IS but min for AIJ. 
International Journal of Trend in Scientific Research and Development (IJTSRD) @ www.ijtsrd.com eISSN: 2456-6470

Table 14: Concrete design of column according as per their code loading

\begin{tabular}{|c|c|c|c|c|}
\hline Code & Main reinforcement & Shear reinforcement & Required area $\left(\mathrm{mm}^{2}\right)$ & Percentage of steel \\
\hline IS456 & 24\#20Ø & 2 legged 8 Ø@280mmc/c & 7539.82 & 1.23 \\
\hline EC-2 & $4 \# 20 \emptyset(\mathrm{TOP}) 4 \# 12 \varnothing(\mathrm{BOTTOM})$ & 1 legged 8 Ø@157mmc/c & 223.19 & 1.25 \\
\hline ACI & $5 \# 20 \emptyset(\mathrm{TOP}) 6 \# 16 \emptyset(\mathrm{BOTTOM})$ & 2 legged 8 Ø@245mmc/c & 1474 & 1.00 \\
\hline AIJ & $3 \# 20 \emptyset(\mathrm{TOP}) 5 \# 16 \emptyset(\mathrm{BOTTOM})$ & 2 legged 12 Ø@245mmc/c & 1470.265 & 1.31 \\
\hline
\end{tabular}

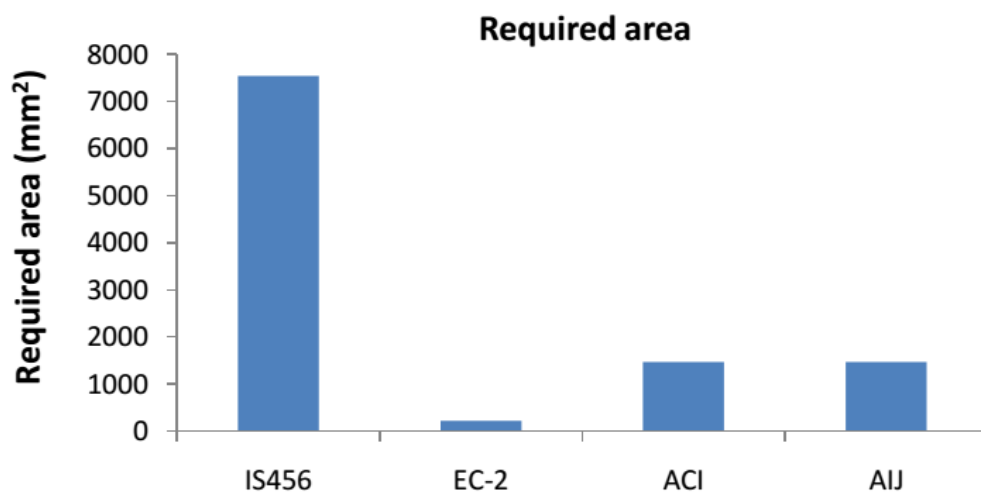

Different country code

Fig.26. Required area as per different code

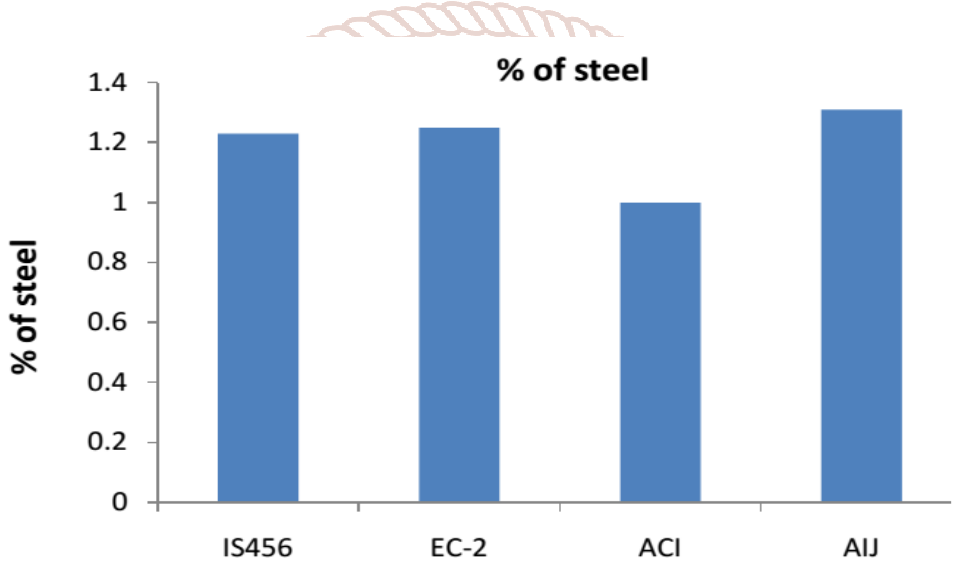

Different country code

Fig.27. \% of steel as per different code

The concrete design of column in table 12 as per their loading condition and its graphical results shows that the value of required area in column is max for IS but the min for EC. The value of $\%$ steel in column is max for AIJ but min for ACI.

\section{Conclusion:-}

The following conclusions are drawn from the computer simulation program carried out in this investigation:

\section{A. For Beam:-}

(i) Analysis as per IS loading-

1. Axial force is maximum as per IS \& EC and minimum as per BSLJ.

2. Bending moment is maximum as per IS \& EC and minimum as per ASCE \& BSLJ.

3. Shear force is maximum as per EC and minimum as per BSLJ.

(ii) Analysis as per their loading-

1. Axial force is maximum as per EC and minimum as per BSLJ.

2. Bending moment is maximum as per EC and minimum as per BSLJ.
3. Shear force is maximum as per ASCE and minimum as per BSLJ.

(iii) Concrete design as per IS loading

1. Required area is maximum as per $\mathrm{ACI}$ and minimum as per IS.

2. Percentage of steel is maximum as per IS and minimum as per AIJ.

(iv) Concrete design as per their loading

1. Required area is maximum as per IS and minimum as per BSLJ.

2. Percentage of steel is maximum as per IS and minimum as per AIJ.

\section{B. For Column:-}

(i) Analysis as per IS loading-

1. Axial force is maximum as per ASCE \& BSLJ and minimum as per EC.

2. Bending moment is maximum as per ASCE and minimum as per BSLJ.

3. Shear force is maximum as per ASCE and minimum as per BSLJ.

4. Base shear is maximum as per IS, EC \& BSLJ and minimum as per ASCE. 
(ii) Analysis as per their loading-

1. Axial force is maximum as per ASCE \& BSLJ and minimum as per EC.

2. Bending moment is maximum as per ASCE and minimum as per BSLJ.

3. Shear force is maximum as per ASCE and minimum as per BSLJ.

4. Base shear is maximum as per IS, BSLJ \& EC and minimum as per ASCE.

(iii) Concrete design as per IS loading

1. Required area is maximum as per EC and minimum as per AIJ.

2. Percentage of steel is maximum as per AIJ and minimum as per ACI.

(iv) Concrete design as per their loading

1. Required area is maximum as per IS and minimum as per EC.

2. Percentage of steel is maximum as per AIJ and minimum as per ACI.

Reference:-

[1] Yuji Ishiyama: Introduction to Earthquake Engineering and Seismic Codes in the World, July 2012,http://iisee.kenken.go.jp/

[2] Muhammad Mostafijur Rahman, Sagar m. Jadhav, Bahram M. Shahrooz, seismic performance of reinforces concrete building designed according to codes in Bangladesh, India and U. S. University of Cincinnati, USA.

[3] Ahmad M. EI-Kholy, Hoda Syed, Ayman A. Shaheen, Comparison of Egyptian code 2012 with Euro code 82013, IBC 2015 and UBC 1997 for seismic analysis of residential shear-wall RC buildings in Egypt Volume 9, Issue 4, Pages 3425-3436, Nahda University NUB, Beni Suef. Egypt, 2018.

https://en.wikipedia.org/wiki/1908_Messina_earthqua ke

[4] IS-1893 Part 1. Criteria of earthquake resistant design of the structure, rev. 5, Bureau of Indian standards, Manak Bhawan, New Delhi, India 2002.

[5] S. Otani, Recent developments in seismic Design criteria in Japan. In proceedings of an $11^{\text {th }}$ world conference of earthquake engineering (11 th WCEE), paper no. 2124.

[6] S. Otani, Japanese seismic design of High rise reinforces concrete building-an example of performance-based design code and state of practice. In proceedings of a $13^{\text {th }}$ world conference of earthquake engineering $\left(13^{\text {th }}\right.$ WCEE), paper no. 5010 .

[7] CEN/TC 250 Committee. Euro code 8. Design of structure for earthquake resistant, part 1: General rules for buildings (European standard EN 1998-1) European Committee for Standardization (CEN); Belgium-2004

[8] CEN/TC 250 Committee. Euro code 8. Design of structure for earthquake resistant, part 1: General rules for buildings (European standard EN 1998-1) European Committee for Standardization (CEN); Belgium-2013ACI Committee 318.

[9] ACI 318-14/ACI 318R-14, building code requirements for structural concrete and commentary. Farmington Hills, MI: American Concrete Institute; 2014.
[10] ASCE/SEI 7-10. Minimum design loads for buildings and other structures. Reston, VA: American Society of Civil Engineers; 2010

[11] Edoardo M. Marino, Masayoshi Nakashima, and Khalid M. Mosalam Comparison of European and Japanese seismic design of steel building structures Kyoto University, Gokasho, Uji, Kyoto 611-0011, Japan Engineering Structures 27 (2005) 827-840

[12] Marjan Faizian and Yuji Ishiyama comparison of seismic codes of 1981 Japan (BSLJ), 2000 USA (IBC) and 1999 Iran (ICS) $13^{\text {th }}$ World Conference on Earthquake Engineering Vancouver, B.C., Canada August 1-6, 2004 Paper No. 3168.

[13] C. Bhatt, R. Bento A Comparison Between American and European Codes on the Nonlinear Static Analysis of RC Buildings $15^{\text {th }}$ World Conference on Earthquake Engineering.

[14] By Weizi Zhang and Bahram M. Shahrooz Comparison between ACI and AISC for concrete-filled tubular columns, Heriot-Watt University on $03 / 07 / 15$ Copyright ASCE.

[15] Ang' Elica Walsh, Daniel C' Ostola, Lucila C. Labaki Comparison of three climatic zoning methodologies for building energy efficiency applications, http://dx.doi.org/doi:10.1016/j.enbuild.2017.04.044

[16] Sameh A. EI-Betar Seismic performance of the existing framed building, http://ees.elsevier.com/hbrcj

[17] Ali Ergun, Nevzat kirac, Veli Bas, Aran The evaluation of structural properties of a reinforced concrete building designed according to pre-modern code considering seismic performance

Doi:10.1016/j.engfailanal.2015.09.003, Reference: EFA 2693.

[18] Ali Ruzi Ozuygur Performance-based seismic design of an irregular tall building - a case study, Doi:10.1016/j.istruc.2015.10.00 Reference: INSTRUCT 62.

[19] Leonardo Avila, Graça Vasconcelos, Paulo B. Lourenço. Experimental seismic performance assessment of asymmetric masonry buildings, www.elsevier.com/locate/engstruct

[20] Mohsen Kahurangi, Laurentiu Danciu, Paolo Bazzurro. Comparison between outcomes of the 2014 Earthquake Hazard Model of the Middle East (EMME14) and national seismic design codes: The case of Iran, www.elsevier.com/locate/soildyn

[21] Kristijan Kolozvari, Vesna Terzic, Ross Miller, Daniel Saldana. Assessment of dynamic behavior and seismic performance of a high-rise RC coupled wall building, www.elsevier.com/locate/engstruc

[22] A. Mosleh, H. Rodrigues, H. Varum, A. Costa, A. Arêde. Seismic behavior of RC building structures designed according to current codes, www.elsevier.com/locate/structures

[23] José Barros, Hern án San ta-María. Seismic design of low -rise buildings based on frequent earthquake response spectrum https: / /Doi .org/10.1016/ j .job e.2018.11.005

[24] S. Malekpour, P. Seyyedi, F. Dashti, and J. Fallah Asghari. Seismic Performance Evolution of Steel Moment Frames Using Iranian, Euro code and Japanese code, The Twelfth East Asia-Pacific Conference on Structural 
Engineering and Construction, Procedia Engineering 14 (2011) 3331-3337.

[25] Gang Shi, Fangxin Hu, Yongjiu Shi. Comparison of seismic design for steel moment frames in Europe, the United States, Japan and China, Journal of Constructional Steel Research 127 (2016) 41-53.

[26] Masaomi Teshigawara Outline of Earthquake Provisions in the Japanese Building Codes Architectural Institute of Japan (ed.), Preliminary Reconnaissance Report of the 2011 Tohoku-Chiho Taiheiyo-Oki Earthquake, Geotechnical, Geological and Earthquake
Engineering 23, DOI 10.1007/978-4-431-54097-7, (C) Springer Japan 2012.

[27] CEN. Euro Code 8: Final draft of Euro Code 8: Design of structures for earthquake resistance - 1998-1:2004: General rules, seismic actions, and rules for buildings. Bruxelles: European Committee for Standardization; 2003

[28] F. Biasioli, G. Mancini, M. Just, M. Curbach, J. Walraven, S. Gmainer, J. Arrieta, R. Frank, C.Morin, F. Robert EUROCODE 2: Background \& Applications design of concrete buildings by European commission 2014. 